\title{
Pengaruh LDR, NIM Dan ROA terhadap Return Saham (Studi Kasus pada Bank Umum yang Terdaftar di Bursa Efek Indonesia 2014-2017)
}

\author{
Any Rustia Dewi \\ Fakultas Ekonomi dan Bisnis, Universitas Merdeka Malang, Malang \\ anyrustia@unmer.ac.id
}

\begin{abstract}
This study aims to analyze the effect of Loan to Deposit Ratio (LDR), Net Interest Margin (NIM), and Return on Assets (ROA) on Stock Return. This research population are all banks that listed in Indonesia Stock Exchange (IDX) 2014-2017, with number of sample 13 banks selected by purposive random sampling. The data is analyzed by multiple linear regression analysis. The result of data analysis shows that only Return of Assets (ROA) has a significant effect on stock return.
\end{abstract}

Keywords : Loan to Deposit Ratio (LDR), Net Interest Margin (NIM), Return on Assets (ROA), Stock Return

\section{PENDAHULUAN}

Ketatnya persaingan

bisnis

perbankan untuk mendapatkan pertumbuhan pendapatan komisi atau fee based income, menuntut bank dalam meningkatkan transaksinya. Perusahaan sebagai suatu entitas yang beroperasi dengan menerapkan prinsip-prinsip ekonomi, umumnya tidak hanya berorientasi pada pencapaian laba maksimal, tetapi juga berusaha meningkatkan niai perusahaan dan kemakmuran pemiliknya (Napa I. Awat dan Muljadi, 1995:29). Untuk itu, bank harus memiliki rencana strategis untuk mencapai peningkatan laba tiap tahunnya. Sementara perbankan saat ini dinilai masih sedikit mengalami kendala likuiditas, yang menyebabkan terbatasnya penyaluran kredit yang mengarah pada stagnasi pertumbuhan Loan to Deposit ratio (LDR). Hal tersebut ditunjukkan pada bulan Maret 2017, rasio simpanan dan kredit perbankan mencapai 88,9\%. Pencapaian rasio LDR tersebut hanya tumbuh tipis dibandingkan dengan data pada bulan Maret 2016 sebesar 87,58\%.

Sedangkan, secara month-to-month, LDR pada bulan Februari dan Januari 2017 masing-masing tercatat $88,89 \%$ dan $94,18 \%$. Banyak bankir berpendapat Perbankan masih perlu adanya kenaikan dana murah agar Dana Pihak Ketiga (DPK) terus tumbuh tanpa menambah beban biaya (cost of fund). Sementara, DPK dinilai masih ketat pada Maret 2017 dengan kredit perbankan yang tumbuh 9,24\%. Besaran nilai DPK hanya tumbuh 10,02\%, itupun dengan mayoritas DPK berasal dari dana mahal, yakni deposito bertenor 1 (satu) hingga 3 (tiga) bulan.

Berdasar Rencana Bisnis Bank (RBB) 2017 yang diserahkan bank ke Otoritas Jasa Keuangan (OJK) (JawaPos.com), beberapa bankir memproyeksi sampai akhir 2017 LDR perbankan berada di angka 94,18\% atau naik dari LDR 2016 sebesar 93,09\%. Dengan proyeksi LDR yang tumbuh terbatas, bank 
harus mendorong transaksi dari pemilik dana murah agar laba terus berjalan. Selain itu, para ekonom banyak menilai tahun ini perebutan bunga bersih oleh perbankan akan menghadapi persaingan yang ketat (detik.com). Ekonom memproyeksikan Net Interest Margin (NIM) atau pendapatan bunga tidak akan sebesar tahun lalu. Data Statistik Perbankan Indonesia (SPI) mencatat NIM perbankan nasional per Maret 2017 sebesar 5,38\% atau sekitar Rp 335,79 triliun dari rata-rata total aset produktif $\mathrm{Rp}$ 6.240,5 trilun. Sedangkan posisi akhir 2016 nilai NIM sebesar 5,63\% yakni sekitar Rp 329,91 triliun dari aset produktif Rp 5.854,7 triliun. Kemudian periode 2015 NIM tercatat 5,39\% atau Rp 293,82 triliun dari aset produktif Rp 5.449,6 triliun. Kemungkinan menurunnya NIM perbankan akibat dari DPK murah yang terbatas dapat terjadi. Adapun kemungkinan lainnya pada penurunan pendapatan komisi atau fee based income perbankan juga dapat dipengaruhi oleh perubahan rasio simpanan atau LDR, dan tingkat pertumbuhan kredit.

\section{Teori Signaling}

Pihak internal perusahaan memiliki informasi yang lengkap mengenai kondisi perusahaan pada saat ini maupun masa yang akan datang. Informasi tersebut lebih lengkap, relevan dan akurat dibandingkan dengan pihak eksternal perusahaan antara lain investor dan pelaku bisnis. Signaling theory menjelaskan mengapa perusahaan mempunyai dorongan untuk memberikan informasi laporan keuangan terhadap pihak luar perusahaan. Dorongan tersebut diperlukan untuk memberikan informasi karena terdapat asimetri informasi antara perusahaan dengan pihak eksternal. Kurangnya informasi bagi pihak luar mengenai perusahaan berujung pada sikap melindungi diri mereka dengan memberikan harga yang rendah bagi perusahaan. Perusahaan dapat menaikkan nilai perusahaan dengan mengurangi asimetri informasi. Jusny (2014) menyatakan bahwa teori sinyal adalah teori yang menjelaskan tentang bagaimana manajer perusahaan memberikan sinyal kepada pihak luar perusahaan. Sinyal dapat berwujud dalam berbagai bentuk, baik yang dapat diamati secara langsung maupun harus dilakukan analisis yang mendalam terlebih dahulu sehingga pihak luar perusahaan akan melakukan perubahan penilaian atas perusahaan (Gumanti, 2009). Dengan adanya laporan keuangan yang lengkap, akurat dan relevan dari pihak perusahaan dapat membantu pelaku bisnis dalam menilai kondisi keuangan bank. Menurut peraturan Bank Indonesia terdapat lima aspek penilaian penting dalam perbankan yakni CAMELS (Capital, Asset, Management, Earning, Liquitdity). Dimana aspek capital ditunjukkan dengan CAR (Capital Adequacy Ratio), aspek aset ditunjukkan dengan NPL (Non Performing Loan), aspek earning ditunjukkan NIM (Net Interest Margin) dan BOPO (Biaya Operasional dan Pendapatan Operasional, dan aspek likuiditas ditunjukkan dengan LDR (Loan to Deposit Ratio) dan GWM (Giro Wajib Minimum). Sedangkan dalam mengukur profitabilitas perbankan biasanya menggunakan ROA (Return On Asset). Rasio ini ditujukan untuk mengukur kemampuan perusahaan dalam memperoleh pendapatan dalam menjalankan usahanya. Apabila ROA terjadi kenaikan, maka berarti profitabilitas perusahaan pun meningkat. Beberapa faktor yang dapat mempengaruhi nilai ROA yakni: 1) CAR mengukur tingkat kecukupan permodalan perbankan; 2) BOPO merupakan rasio efisiensi perusahaan; 3) NIM merupakan marjin rasio yang berupa selisih antara pendapatan bunga dengan biaya bunga; dan 4) LDR yang mengukur besarnya dana pihak ketiga Bank yang ditujukan untuk penyaluran kredit.

\section{Pengaruh LDR (Loan To Deposit Ratio) terhadap Return Saham}

Sofyan (2010:201), mengemukakan rasio likuiditas merupakan rasio yang mengukur kemampuan perusahaan memenuhi kewajiban jangka pendeknya. Dalam perusahaan perbankan rasio likuiditas merupakan rasio untuk mengukur 
kemampuan suatu bank dalam memenuhi kewajiban jangka pendeknya saat ditagih. Kewajiban bank dalam jangka pendek sebagai kewajiban-kewajiban yang akan jatuh tempo dalam kurun waktu kurang dari satu tahun. Rasio likuiditas yang umumnya digunakan dalam dunia perbankan disebut Loan to Deposit Ratio (LDR). Menurut Lukman (2009), LDR merupakan rasio antara seluruh jumlah kredit yang diberikan dengan dana yang diterima oleh bank untuk mengukur kemampuan bank dalam membayar kembali penarikan dana yang dilakukan deposan dengan mengandalkan kredit yang diberikan sebagai sumber likuiditasnya. Menurut UU Perbankan no. 10 tahun 1998 dan UU no. 3 tahun 2014, LDR adalah kredit yang diberikan merupakan kegiatan usaha utama bank untuk memperoleh pendapatan. Sedangkan, dana pihak ketiga merupakan dana simpanan yang berasal dari masyarakat yang terdiri dari tabungan, giro dan deposito (Lukman, 2009). Risiko yang ditanggung oleh bank akan semakin besar sebanding dengan besarnya tingkat penyaluran dana oleh bank dalam bentuk kredit.

Bagi investor, besarnya LDR menunjukkan banyaknya dana yang disalurkan dalam bentuk kredit, yang tujuannya untuk menghasilkan laba dari bunga kredit. Hal tersebut akan mempengaruhi penilaian investor dalam mengambil keputusan investasinya, sehingga secara bersamaan akan mempengaruhi permintaan saham di pasar modal yang pada akhirnya akan mempengaruhi harga saham dan berdampak pada pertumbuhan tingkat return saham (Ryan, 2012). Eduardus (2001:47), mengemukakan return merupakan salah satu faktor yang memotivasi investor berinvestasi dan juga merupakan imbalan atas keberanian investor menanggung risiko atas investasi yang dilakukannya.

LDR merupakan rasio yang mendeskripsikan perbandingan antara kredit yang disalurkan oleh bank dengan jumlah dana pihak ketiga yang dihimpun oleh bank. Dimana, dana pihak ketiga tersebut berasal dari giro, tabungan dan deposito. Dengan demikian besaran dana pihak ketiga yang dihimpun oleh suatu bank, berbanding lurus dengan besaran kredit yang disalurkan oleh bank tersebut. Bank dengan tingkat agresitas tinggi tercermin dari angka LDR, yang dapat mencapai diatas 110\%. Bank Indonesia mengatur tingkat LDR perbankan di angka 80 hingga 110 persen. Semakin tinggi tingkat LDR perbankan maka laba akan semakin tinggi, yang berarti bahwa bank dapat menyalurkan kreditnya secara efektif. Meskipun, bank dapat secara potensial dapat mengalami kesulitan likuiditas akibat dari penggunaan LDR yang tinggi, jika tidak diimbangi dengan cash inflow yang memadai akibat tidak sebandingnya antara pembayaran bunga dari debitur dengan kebutuhan bank untuk memenuhi cash outflow dari penarikan dana giro, tabungan dan deposito yang jatuh tempo kepada nasabah bank.

Hasil penelitian mengenai Loan to Deposit Ration (LDR) terhadap return saham menunjukkan hasil yang berbedabeda. Hasil penelitian Rahmi (2004) dan Asna (2006) menunjukkan bahwa LDR berpengaruh terhadap return saham. Hasil tersebut berbeda dengan hasil penelitian Suardana (2009), Risky (2009) dan Ingga (2013) yang menunjukkan LDR tidak berpengaruh terhadap return saham. Sedangkan, penelitian Rintistya (2012) menunjukkan LDR berpengaruh terhadap return saham.

\section{Pengaruh Kualitas Aktiva Produktif NIM (Net Interest Margin) terhadap Return Saham}

$\begin{array}{cccc}\text { NIM } & \text { (Net Interest Margin) } \\ \text { merupakan pendapatan bunga kredit }\end{array}$ dikurangi biaya bunga simpanan terhadap outstanding kredit rasio yang menunjukkan kemampuan bank dalam mendapatkan pendapatan operasinya. Semakin tinggi marjin rasio maka bank dinilai semakin efektif dalam menempatkan aktiva perusahaan dalam bentuk kredit. Pengaruh 
NIM terhadap ROA dinilai menunjukkan pengaruh yang positif artinya semakin tinggi pendapatan bunga yang diperoleh dari kredit yang disalurkan olek perbankan maka akan terjadi peningkatan laba.

Hasil penelitian terhadap Net Interest Margin (NIM) terhadap return saham juga menunjukkan hasil yang berbeda-beda. Hasil penelitian Fathoni (2010) dan Marviana (2009) menunjukkan bahwa NIM berpengaruh terhadap return saham. Hasil penelitian tersebut berbeda dengan penelitian Martoyo (2007) dan Risky (2009) menunjukkan bahwa NIM tidak berpengaruh terhadap return saham. Sedangkan, penelitian Rintistya (2012) menunjukkan NIM berpengaruh terhadap return saham.

\section{Pengaruh ROA (Return On Asset) terhadap Return Saham}

Kasmir (2006) mengartikan rasio rentabilitas sering disebut profitabilitas usaha dan digunakan untuk mengukur tingkat efesiensi usaha dan profitabilitas yang dicapai oleh bank. Hal tersebut menjelaskan bahwa rasio rentabilitas selain bertujuan untuk mengetahui kemampuan bank dalam menghasilkan laba selama periode tertentu, juga bertujuan untuk mengukur tingkat efektivitas manajemen dalam menjalankan operasional perusahaannya.

Profitabilitas yaitu sekelompok rasio yang menunjukkan pengaruh gabungan dari likuiditas, pengelolaan Aset, dan pengelolaan utang terhadap hasil-hasil operasi. Dengan kata lain profitabilitas adalah hasil bersih dari serangkaian kebijakan dan keputusan atas rasio-rasio yang termasuk dalam profitabilitas tidak lain seperti Return on Assets (ROA) dan Return on Equity (ROE) (Weston dan Brigham, 1994:304). Sedangkan Bank Indonesia dalam menghitung rentabilitas bank lebih menitikberatkan kepada penilaian Return on Asset (ROA). Hal tersebut dikarenakan nilai profitabilitas dianggap merupakan hal utama yang diukur, dimana sebagian besar aset bank berasal dari dana simpanan masyarakat
(Lukman, 2009:119). Sesuai Surat Edaran Bank Indonesia no. 13/24/DPNP tanggal 25 Oktober 2011, ROA perbankan diperoleh dengan cara membandingkan antara laba sebelum pajak atau earning before interest tax (EBIT) terhadap rata-rata total aset. Apabila setiap tahunnya bank menghasilkan laba positif. Hal ini memberikan sinyal bagi investor bahwa semakin tinggi nilai ROA, maka kemampuan bank dalam menghasilkan keuntungan akan semakin tinggi. Hal ini akan mendorong harga saham yang pada akhirnya akan berdampak pada kenaikan return saham (Eduardus 2001).

Hasil penelitian mengenai Ingga (2013) menunjukkan Return on Assets (ROA) mempunyai pengaruh positif dan signifikan terhadap return saham.

Berdasarkan kajian teori maupun kajian empiris di atas, hipotesis dalam penelitian ini dapat dirumuskan sebagai berikut:

$\mathrm{H}_{1}=$ Tingkat pengembalian aset (ROA) berpengaruh positif signifikan terhadap return saham.

$\mathrm{H}_{2}=$ Tingkat kemampuan bank dalam menyalurkan dananya (LDR) berpengaruh positif signifikan terhadap return saham.

$\mathrm{H}_{3}=$ Kemampuan bank dalam mengelola aktiva produktif untuk menghasilkan laba bersih (NIM) berpengaruh positif signifikan terhadap return saham.

\section{METODE}

Penelitian ini dilakukan pada perusahaan perbankan yang terdaftar di Bursa Efek Indonesia (BEI) pada tahun 2014-2017. Jenis data yang digunakan dalam penelitian ini adalah data kuantitatif dan sumber data yang digunakan merupakan data sekunder. Data sekunder yang digunakan dalam penelitian ini didapat dari hasil publikasi laporan keuangan industri perbankan maupun dari informasi kinerja saham perbankan di BEI. Sampel data untuk analisis dalam pengujian penelitian ini harus memenuhi 
syarat yaitu: 1) Tersedianya data laporan keuangan selama kurun waktu penelitian yakni tahun 2014 sampai dengan tahun 2017; 2) Bank yang diteliti adalah bank umum dan masih beroperasi saat periode waktu penelitian; 3) Bank tidak dalam masa melakukan aksi korporasi seperti stock split maupun merger dan akuisisi dalam periode tersebut; 4) Bank tidak dalam pengawasan otoritas Bursa Efek Indonesia yang terlambat dalam penyampaian laporan keuangan pada periode penelitian; 5) Perusahaan memiliki data pergerakan harga yang lengkap dalam periode penelitian; dan 6) Perusahaan memiliki data perdagangan harga saham yang aktif dan likuid dalam periode penelitian. Sehingga berdasarkan kriteria tersebut maka jumlah sampel yang didapat dan digunakan dalam penelitian ini berjumlah 13 Bank Umum.

\section{HASIL DAN PEMBAHASAN}

Penelitian ini menggunakan data dalam bentuk cross section. Penelitian dilakukan pada tahun 2014 sampai dengan 2017 dan sampel yang digunakan sebanyak 13 perusahaan, maka secara cross section diperoleh sejumlah 13 perusahaan x 4 tahun = 52 data observasi. Analisis data deskriptif berikut bertujuan memberikan gambaran atau deskripsi mengenai variabel yang dianalisis yakni, ROA (X1), LDR (X2) dan NIM (X3). Analisis data deskriptif yang akan dilakukan bertujuan untuk memberikan gambaran atau deskripsi mengenai variabel penelitian. Hal tersebut dijelaskan dalam tabel 1 berikut ini:

Tabel 1. Analisis Data Deskriptif

\begin{tabular}{|l|r|r|r|r|r|r|r|r|}
\hline \multicolumn{7}{|c|}{ Descriptive Statistics } \\
\hline & N & Range & Min. & Max. & Sum & \multicolumn{2}{|c|}{ Mean } & Std. Dev. \\
\hline Y & 52 & 141 & -50 & 91 & 867 & 16,68 & 4,21 & 30,38 \\
X1 & 52 & 9 & -5 & 4 & 81 & 1,55 &, 20 & 1,44 \\
X2 & 52 & 58 & 52 & 109 & 4373 & 84,10 & 1,80 & 12,98 \\
X3 & 52 & 10 & 2 & 12 & 292 & 5,61 &, 30 & 2,17 \\
\hline
\end{tabular}

Sumber data: diolah

Tabel 1 menunjukkan berdasarkan pehitungan selama periode penelitian, didapatkan nilai minimum pada variabel return saham sebesar -50 persen, artinya perbandingan harga saham pada periode tahun tersebut dengan harga saham periode sebelumnya mengalami penurunan sebesar 50 persen. Nilai maksimum return saham sebesar 91 persen menunjukkan bahwa perbandingan harga saham pada periode tahun tersebut dengan harga saham periode sebelumnya sebesar 91 persen. Kemudian nilai range merupakan selisih nilai minimum dan maksimum yakni sebesar 141 dan nilai sum merupakan penjumlahan dari nilai harga saham ke 52 sampel yaitu sebesar 867. Rata-rata nilai dari 52 data yang diteliti dari return saham perbankan atau mean sebesar 16,68 persen dengan standar deviasi sebesar 30,38.

Nilai minimum pada Return on Assets (X1) adalah -5 persen, dan nilai maksimum sebesar 4 persen. Nilai sum merupakan penjumlahan dari nilai tingkat pengembalian aset dari 52 data yaitu 81 . Rata-rata nilai dari sampel yang diteliti atau mean sebesar 1,55 persen dengan standar deviasi sebesar 1,44.

Pada nilai minimum variabel Loan to Deposit Ratio (X2) adalah 52 persen, dan nilai maksimum sebesar 109 persen. Nilai sum merupakan penjumlahan dari nilai likuiditas perbankan dari 52 data yaitu sebesar 4.373. Rata-rata nilai dari sampel yang diteliti atau mean sebesar 84,1 persen dengan standar deviasi sebesar 12,98.

Sedangkan nilai minimum variabel Net Interest Margin (X3) adalah 2 persen, dan nilai maksimum sebesar 12 persen. Nilai sum merupakan penjumlahan dari tingkat marjin perbankan dari 22 data yaitu sebesar 292. Rata-rata nilai dari sampel yang diteliti atau mean sebesar 5,61 persen dengan standar deviasi sebesar 2,17.

Penelitian ini menggunakan model persamaan, yaitu analisis regresi linear berganda. Sebelum melakukan analisis regresi linier berganda yang digunakan untuk menguji hipotesis, maka terlebih dahulu dilakukan pengujian asumsi klasik yang meliputi uji normalitas, uji autokorelasi, uji multikolinieritas, dan uji 
heteroskedastisitas. Uji normalitas merupakan suatu uji statistik yang bertujuan untuk menguji apakah dalam residual dari model regresi yang dibuat berdistribusi normal atau tidak. Data dikatakan berdistribusi normal jika nilai Asyp.sig (2-tailed) > level of significant $(\alpha)$ $=5 \%$.

Hasil dari uji normalitas pada tabel 2, memperlihatkan bahwa variabel ROA, LDR, dan NIM berdistribusi normal dimana nilai Asymp.sig (2-tailed) sebesar 0,851 lebih besar dari tingkat signifikansi 0,05.

Tabel 2. Uji Normalitas

One-Sample Kolmogorov-Smirnov Test

\begin{tabular}{llr}
\hline & & $\begin{array}{r}\text { Unstandardi ed } \\
\text { Residual }\end{array}$ \\
\hline $\mathrm{N}$ & Mean & 52 \\
Normal & $\begin{array}{r}\text { R.4780376 } \\
\text { Parameters }\end{array}$ & \\
& Std. & 29.25885341 \\
Most Extreme & Deviation & .085 \\
Differences & Absolute & .085 \\
& Positive & -.045 \\
Kolmogorov-Smirnov Z & .610 \\
Asymp. Sig. (2-tailed) & .851 \\
\hline
\end{tabular}

Sumber data: diolah

Uji autokorelasi (tabel 3) bertujuan untuk mengetahui adanya korelasi auto atau pengaruh data dari uji pengamatan sebelumnya dalam model regresi. Uji run test dengan nilai lebih dari 0,05 menunjukkan bahwa tidak terjadi autokorelasi. Hal tersebut ditunjukkan oleh nilai Asymp.sig (2-tailed) sebesar 0,401 lebih besar dari tingkat signifikansi 0,05.

Tabel 3. Uji Autokorelasi

\begin{tabular}{lr}
\multicolumn{2}{c}{ Runs Test } \\
\hline & $\begin{array}{c}\text { Unstandardi ed } \\
\text { Residual }\end{array}$ \\
\hline Test Value $^{\mathrm{a}}$ & -6.83567 \\
Cases $<$ Test Value & 26 \\
Cases >= Test Value & 26 \\
Total Cases & 52 \\
Number of Runs & 24 \\
Z & -.840 \\
Asymp. Sig. (2-tailed) & .401 \\
\hline Sumber data: diolah
\end{tabular}

Uji multikolinieritas bertujuan untuk menguji apakah pada model regresi ditemukan adanya korelasi antar variabel bebas. Berdasarkan tabel 4 dibawah ini, diketahui nilai Tolerance untuk variabel ROA adalah sebesar 0,674, LDR 0,860 dan NIM 0,622. Ketiga variabel tersebut memiliki nilai Tolerance lebih besar dari 0,10 . Sementara, nilai VIF untuk variabel ROA sebesar 1,483, LDR 1,163 dan NIM 1,608. Maka mengacu pada dasar pengambilan keputusan dalam uji multikolinearitas dapat disimpulkan bahwa tidak terjadi gejala multikolineritas dalam model regresi.

Tabel 4. Uji Multikolinearitas

Coefficients

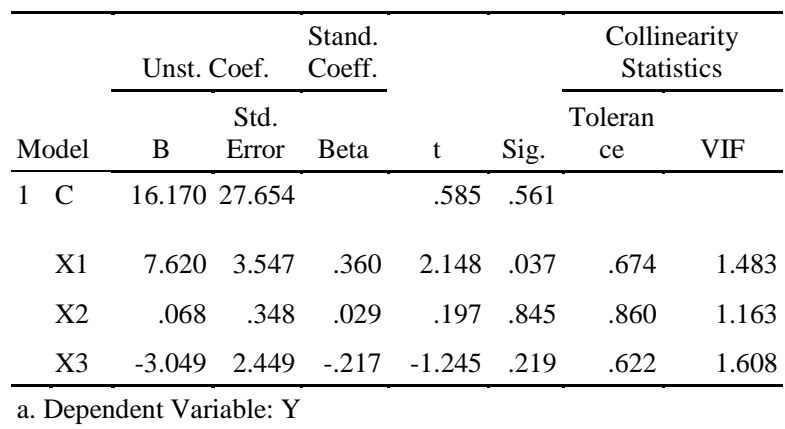

Uji heteroskedastisitas bertujuan untuk menguji apakah dalam model regresi terjadi ketidaksamaan varians dari residual suatu pengamatan terhadap pengamatan lain. Dari output tabel 5 dibawah ini diketahui bahwa bahwa nilai signifikansi atau Sig. (2tailed) variabel ROA 0,740, LDR 0,537 dan NIM 0,873. Karena nilai ketiga variabel independen tersebut lebih besar dari nilai 0,05 sehingga dapat disimpulkan bahwa tidak terdapat masalah atau gejala heteroskedastisitas. Artinya model regresi yang digunakan dalam penelitian ini layak untuk dilakukan. 
Tabel 5. Uji Heteroskedastisitas

\begin{tabular}{|c|c|c|c|c|c|c|}
\hline \multicolumn{7}{|c|}{ Correlations } \\
\hline & & & X1 & X2 & X3 & $\begin{array}{l}\text { Abs } \\
\text { RES }\end{array}$ \\
\hline \multirow{12}{*}{$\begin{array}{l}\text { Spe } \\
\text { arm } \\
\text { an's } \\
\text { rho }\end{array}$} & \multirow[t]{3}{*}{$\mathrm{X} 1$} & Cor. Coef. & 1.000 & $.421^{* *}$ & $.759^{* *}$ & .047 \\
\hline & & Sig. & . & .002 & .000 & .740 \\
\hline & & $\mathrm{N}$ & 52 & 52 & 52 & 52 \\
\hline & \multirow[t]{3}{*}{$\overline{x 2}$} & Cor. Coef. & $.421^{\star \star}$ & 1.000 & $.427^{\star \star}$ & -.088 \\
\hline & & Sig. & .002 & & .002 & .537 \\
\hline & & $\mathrm{N}$ & 52 & 52 & 52 & 52 \\
\hline & \multirow[t]{3}{*}{ X3 } & Cor. Coef. & $.759^{* *}$ & $.427^{* *}$ & 1.000 & -.023 \\
\hline & & Sig. & .000 & .002 & . & .873 \\
\hline & & $\mathrm{N}$ & 52 & 52 & 52 & 52 \\
\hline & \multirow{3}{*}{$\begin{array}{l}\text { Abs } \\
\text { RES }\end{array}$} & Cor. Coeff & .047 & -.088 & -.023 & 1.000 \\
\hline & & Sig. & .740 & .537 & .873 & \\
\hline & & $\mathrm{N}$ & 52 & 52 & 52 & 52 \\
\hline
\end{tabular}

**. Correlation is significant at the 0.01 level (2tailed).

Sumber data: diolah

Hasil dari pengujian regresi linier berganda dengan menggunakan SPSS menghasilkan rumusan persamaan linier berganda sebagai berikut:

$\mathrm{Y}=16,170+7,620 \mathrm{X} 1+0,068 \mathrm{X} 2-3,049$ $\mathrm{X} 3+\mathrm{e}$

Tabel 6. Analisis Regresi Linear Berganda

\begin{tabular}{|c|c|c|c|}
\hline \multicolumn{4}{|c|}{ Ringkasan Analisis Regresi Multiples } \\
\hline Variabel & $\begin{array}{l}\text { Koefisie } \\
\text { n } \\
\text { Regresi }\end{array}$ & Thitung & Sig. \\
\hline $\begin{array}{l}\text { Konstan } \\
\text { ta }\end{array}$ & 16,170 & & \\
\hline $\mathrm{X} 1$ & 7,620 & 2,148 & 0,037 \\
\hline $\mathrm{X} 2$ & 0,068 & 0,197 & 0,845 \\
\hline $\begin{array}{l}\text { X3 } \\
\text { Fhitung } 1 \\
\text { Rsquare } 0\end{array}$ & $\begin{array}{l}-3,049 \\
70,208 \\
6\end{array}$ & $-1,245$ & 0,219 \\
\hline
\end{tabular}

Sumber data: diolah

Persamaan regresi linier berganda pada tabel 6 di atas, menunjukkan arah masing-masing variabel bebas terhadap variabel terikatnya. Nilai Konstanta sebesar 16,170 menunjukkan bahwa return saham meningkat sebesar 16,170\% apabila ROA
(X1), LDR (X2) dan NIM (X3) sama dengan nol. Nilai $ß 1$ adalah 7,620 yang artinya bahwa setiap kenaikan ROA sebesar $1 \%$, maka return saham akan mengalami peningkatan sebesar 7,620\% dengan asumsi variabel lainnya nol (0). Nilai $ß 2$ adalah 0,068 yang menunjukkan bahwa setiap peningkatan LDR terjadi sebesar 1\%, maka return saham akan mengalami kenaikan sebesar 0,068\% dengan asumsi variabel lainnya nol (0). Nilai ß3 adalah -3,049 yang menunjukkan bahwa setiap peningkatan NIM terjadi sebesar 1\%, maka return saham akan mengalami penurunan sebesar 3,049\% dengan asumsi variabel lainnya nol (0).

Uji $\mathrm{t}$ dilakukan untuk menguji apakah variabel Tingkat pengembalian aset, Likuiditas dan tingkat marjin berpengaruh signifikan terhadap variabel return saham.

Hipotesis pertama menyatakan bahwa tingkat pengembalian aset berpengaruh positif signifikan terhadap return saham. Hasil pengujian menunjukkan nilai t hitung 2,148 lebih besar dari $t$ tabel 2,010, maka dapat disimpulkan bahwa hipotesis pertama diterima. Artinya ada pengaruh tingkat pengembalian aset terhadap return saham. Sementara dalam tabel di atas juga diketahui bahwa nilai signifikansi (Sig) variabel Return on Assets (X1) adalah sebesar 0,037. Karena nilai Sig. 0,037 < probabilitas 0,05 sehingga dapat disimpulkan bahwa hipotesis pertama diterima. Artinya ada pengaruh tingkat pengembalian aset terhadap return saham.

Hipotesis kedua menyatakan bahwa tingkat likuiditas berpengaruh positif signifikan terhadap return saham. Hasil pengujian menunjukkan nilai $\mathrm{t}$ hitung $0,197<\mathrm{t}$ tabel 2,010, maka dapat disimpulkan bahwa hipotesis kedua ditolak. Artinya tidak ada pengaruh tingkat likuiditas terhadap return saham. Sementara dalam tabel di atas juga diketahui bahwa nilai signifikansi (Sig) variabel Loan to Deposit ratio (X2) adalah sebesar 0,845. Karena nilai Sig. 0,037 > probabilitas 0,05 sehingga dapat disimpulkan bahwa hipotesis kedua ditolak. Artinya tidak ada 
pengaruh tingkat likuiditas terhadap return saham.

Hipotesis ketiga menyatakan bahwa tingkat marjin bank berpengaruh signifikan terhadap return saham. Hasil pengujian menunjukkan nilai t hitung $-1,245<\mathrm{t}$ tabel -2,010, maka dapat disimpulkan bahwa hipotesis ketiga ditolak. Artinya tidak ada pengaruh tingkat marjin bank terhadap return saham. Sementara dalam tabel di atas juga diketahui bahwa nilai signifikansi (Sig) variabel Net Interest Margin (X3) adalah sebesar 0,219. Karena nilai Sig. 0,219 > probabilitas 0,05 sehingga dapat disimpulkan bahwa hipotesis ketiga ditolak. Artinya tidak ada pengaruh tingkat marjin terhadap return saham.

\section{Kesimpulan}

Berdasarkan pada pembahasan sebelumnya, maka diperoleh kesimpulan variabel tingkat kemampuan bank dalam pengembalian aset berpengaruh positif signifikan terhadap return saham bank. Investor menilai bahwa semakin tinggi nilai Return of Asets (ROA) bank, maka kemampuan bank tersebut dalam menghasilkan keuntungan akan semakin tinggi. Hal ini akan mendorong harga saham yang pada akhirnya akan berdampak pada kenaikan return saham, sehingga menyebabkan kenaikan harga saham bank yang berujung pada kenaikan return saham. Dengan demikian dapat disimpulkan bahwa semakin tinggi ROA bank maka akan semakin tinggi nilai tingkat pengembalian sahamnya (return). Hasil pengujian tersebut menunjukkan bagi investor untuk mengambil keputusan dalam melakukan pembelian saham perbankan agar mencermati pergerakan peningkatan nilai ROA secara bertahap dari tahun ke tahunnya untuk mendapatkan imbal hasil investasi yang optimal dalam saham perbankan di Indonesia.

Berdasarkan hasil penelitian, peneliti selanjutnya disarankan untuk: 1) menambah variabel independen yang diduga mempunyai pengaruh terhadap harga saham dari faktor makro perusahaan seperti tingkat suku bunga, tingkat inflasi, dan pertumbuhan ekonomi; dan 2) memperluas besaran populasi penelitian serta memperpanjang periode penelitian dengan tujuan agar hasil penelitian dapat digeneralisasi.

\section{DAFTAR PUSTAKA}

Arkan, T. (2016). The Importance of Financial Ratios in Predicting Stock Price Trends: A Case Study in Emerging Markets. Finanse, Rynki Finansowe, Ubezpieczenia Journal, I(79), 13-26. Diambil dari https://doi.org/10.18276/frfu. 2016.79-01.

Awat, Napa. I, dan Muljadi, 1995, Keputusan-Keputusan Keuangan Perusahaan: Teori dan Hasil Pengujian Empirik Yogyakarta: Liberty.

Brigham, Eguene F dan Joel F. Houston. 2001. Manajemen Keuangan. Edisi Kedelapan. Jalarta: Erlangga

Dianasari, Novita. 2011. Pengaruh CAR, ROE, LDR, dan NPL terhadap Return saham serta Pengaruh Saat Sebelum dan Sesudah Publikasi Laporan Keuangan pada Bank Go Public di Bursa Efek Indonesia.

Eduardus Tandelilin. 2001. Analisis Investasi dan Manajemen Portofolio. Yogyakarta: BPFE.

Efrizon. 2018. Pengaruh Rasio Keuangan Terhadap Harga Saham Perusahaan Otomotif Periode 2013-2017. Jurnal Akuntansi Aktual. Pascasarjana Universitas Andalas.

Gumanti, T.A. (2009). Teori Sinyal dalam Manajemen Keuangan. Diambil Dari https://www.researchgate.net/pub lication/265554191

Harun, Usman. 2003. Pengaruh Ratio-ratio Keuangan CAR, LDR, NIM, BOPO, NPL terhadap ROA. Universitas Sam Ratulangi.

Jogianto. 2010. Teori Portofolio dan Analisis Investasi. Edisi tujuh. Yogyakarta: BPFE UGM.

Kasmir. 2007. Manajemen Perbankan. Jakarta; PT Rajagrafindo Persada. 
Lukman Dendawijaya, 2009. Manajemen Perbankan. Edisi kedua. Ghalia Indonesia. Jakarta.

Riyadi, Selamet (2006). Banking Assets and Liability Management. Lembaga Penerbit Fakultas Ekonomi Universitas Indonesia.

Sofyan Safri Harahap. 2010. Analisis Kritis atas Laporan Keuangan. Jakarta; PT Rajagrafindo Persada.

Syauta Risky, Indra. 2009. : Journal of Applied Finance and Accounting Vol. 1 no. 2 June 2009: 351-367.

Zulfa, Ingga. 2013. Pengaruh Rentabilitas, Likuiditas, Kecukupan Modal dan Ukuran Perusahaan terhadap Return saham pada perusahaan Perbankan yang listing di Bursa Efek Indonesia. 